\title{
Evaluation of consuming fresh pineapple juice (Ananas Comosus) or bromelain on acetic acid-induced ulcerative colitis in rats
}

\author{
Fatma A. Khalil, Nora M. El-Sheikh and Hadeer H. M. Maria \\ Biochemistry and Nutrition Department, Women's College, Ain Shams University, \\ Cairo, Egypt
}

\begin{abstract}
This study aims to evaluate the efficacy of fresh pineapple juice and bromelain consumption on acetic acid-induced ulcerative colitis in rats. Furthermore the study aims to determine the amount of bromelain in fresh pineapple juice by HPLC as well as some of the bioactive constituents of fresh pineapple juice. Sixty male albino rats were divided into six groups; each group consisted of 10 rats. Group (1) served as normal control (Healthy) and group (4) served as positive control (Colitis). Healthy rats of group (2) and colitis rats of group (5) treated with $0.5 \mathrm{ml}$ fresh pineapple juice/100g body weight by stomach tube as well as healthy rats of group (3) and colitis rats of group (6) treated with $0.5 \mathrm{ml}$ bromelain $/ 100 \mathrm{~g}$ body weight daily using stomach tube. The results of chemical analysis of pineapple revealed that each $100 \mathrm{ml}$ of the fresh prepared pineapple juice contains $425 \pm 3.00 \mathrm{mg}$ as gallic acid equivalent (GAE) for total phenols, $584 \pm 4.00 \mathrm{mg}$ as catechin equivalent (CE) for total flavonoids, $25 \pm 1.00 \mathrm{mg}$ for ascorbic acid and $57 \pm 1.00 \%$ as ascorbic acid equivalent (AAE) for total antioxidant capacity. Induction of ulcerative colitis by acetic acid $(0.25 \mathrm{ml}$ of $16 \%$ acetic acid/ $100 \mathrm{~g}$ body weight) markedly increased the oxidative stress which caused significant reduction in nonenzymatic antioxidant such as blood reduced glutathione (GSH), enzymatic antioxidants as serum catalase (CAT) and colon superoxide dismutase (SOD) activities, also resulted in increased lipid peroxidation (LPO) of membranes as colon malondialdehyde (MDA) was significantly increased. Furthermore, serum inflammatory marker levels as tumor necrosis factor- $\alpha$ (TNF- $\alpha$ ), myeloperoxidase (MPO) activity and C-reactive protein (CRP) were significantly increased in colitis rats $(p<0.05)$. While treatment of colitis rats by fresh pineapple juice or bromelain ameliorated the oxidative stress status and decreased inflammatory markers which alleviated the colitis. The microscopic examination of colon sections illustrated the modulating effect of both fresh pineapple juice and bromelain on colon cells. In conclusion, fresh pineapple juice had a better effect than bromelain as its high content of antioxidants as well as bromelain.
\end{abstract}

Key Words: Pineapple juice- Bromelain- Ulcerative colitis- Oxidative stress- Rats.

\section{Introduction}

Inflammatory bowel diseases (IBDs) in humans are comprised of two distinct clinical entities, ulcerative colitis (UC) and Crohn's disease (CD). Intestinal inflammation is primarily confined to the mucosa of the colon and rectum in UC but also involves deeper tissues as well as the small intestine in CD (Hibi et al., 2002).

Corresponding author; Prof.dr. Fatma Abd El-hamid Khalil.

E.mail: fatma_abdelhamed@hotmail.com Tel: 01122205313 
Several etiological factors, such as genetic, immunological and environmental events have been linked with the pathophysiology of the disease (Selling and Pasricha, 2006). Clinically, colitis patients were found to overproduce reactive oxygen species (ROS) and reactive nitrogen species (RNS) leading to lipid peroxidation (LPO) of membranes and attack on tissue proteins and deoxyribonucleic acid (DNA) (Pravda, 2005). In active IBDs, there are increased local production of proinflammatory cytokines, synthesis of eicosanoids, and recruitment of immunologically specific and non-specific inflammatory cells from the circulation (Nisholls, 2002). ROS can cause deoxyribonucleic acid (DNA) modifications and damage. The major sign of these modifications is the formation of 8 hydroxydeoxyguanine (8-OHDG). It was reported that 8-OHDG levels were significantly higher in the inflamed part of the bowel (Alzoghaibi, 2013). These responses of inflammation must be ordered and controlled. The movement of cells into the inflammatory or infected site is induced by the up-regulation of adhesion molecules such as intercellular adhesion molecule (ICAM-1), vascular cell adhesion molecule 1 (VCAM-1), and E-selectin on the surface of endothelial cells, which allows leukocyte binding and subsequent diapedesis. The earliest cells to appear at inflamed sites are granulocytes, with monocytes, macrophages, and lymphocytes appearing later. Granulocytes, monocytes and macrophages are involved in pathogen killing, in clearing up cellular and tissue debris and in tissue repair (Calder, 2006).

Pineapple (Ananas comosus L.) is the leading edible member of the family Bromeliaceae, grown in several tropical and subtropical countries including Philippines, Thailand, Indonesia, Malaysia, Kenya, India and China. It has been used as a medicinal plant in several native cultures and these medicinal qualities of pineapple are attributed to bromelain and others (Mondal et al., 2011). Pineapple is consumed in many parts of the world as fresh fruit, juice, jam, jelly and dried product. It has a high nutritive value and is a rich source of vitamins A, B and C besides several minerals such as calcium, phosphorus and iron (Gardner et al., 2000). Several studies revealed that the majority of the antioxidant activity of pineapple may be from compounds such as flavonoids, isoflavones, flavones, anthocyanins, catechins and other phenolics (Danino et al., 2009, Mhatre et al., 2009 and Isabelle et al., 2010).

Bhattacharyya (2008) stated that bromelain is a crude extract from the fruit or stem of pineapple plant; it consists of different closely related proteinases which are good anti-inflammatory, antithrombotic and fibrinolytic agents. The active fractions have been characterized biochemically and found to be effective after oral administration. It has earned universal acceptability as a phytotherapeutical drug because of its history of safe use and zero side effects.

From the above, this study aims to investigate the anti-inflammatory effect of pineapple and proteolytic enzyme bromelain in experimentally colon inflammation induced in male albino rats. 


\section{Materials and Methods}

Pineapple

The fresh mature pineapple fruit (Ananus comosus) was purchased from local market in Cairo.

Bromelain

Bromelain powder of analytical pure grade was obtained from Sigma-Aldrich Chemicals, St.Louis, MO, USA.

Chemical for colitis induction

Glacial acetic acid used for colitis induction $(0.25 \mathrm{ml}$ of $16 \%$ acetic acid/ $100 \mathrm{~g}$ body weight) was purchased from El- Gomhoria Company (Cairo, Egypt).

Animals

The animals used throughout the experiment were 60 male adult albino rats Wistar strain weighing $180 \pm 10 \mathrm{~g}$, supplied from the Breading Unit of the Egyptian Organization for Biological Products and Vaccines (Helwan, Egypt).

Diet

The experimental diet used in the present study was the balanced diet prepared according to American Institute of Nutrition (AIN-93) and adjusted by Reeves et al. (1993).

Chemical constituents and antioxidant capacity of tested pineapple samples

The chemical constituents and antioxidant capacity of fresh pineapple juice were determined in the form of: total phenols according to the method reported by Singleton et al. (1999), total flavonoids content as indicated by Quettier et al. (2000), ascorbic acid concentration according to the method of AOAC (2006) and total antioxidant capacity by using Prieto et al. (1999) method.

Determination of bromelain concentration in fresh pineapple juice by HPLC

The bromelain concentration in fresh pineapple juice was determined by HPLC as described by (Lopez-Garcia et al., 2012) but for more accuracy in the determination of bromelain in our work, there was a modification of the method, the use of trifloroacetic acid was neglected to avoid precipitation any part of protein (bromelain) and the results were accurately measured at wavelength $210 \mathrm{~nm}$ using Hypersil BDS-C18 (4 x 250 mm, $5 \mu \mathrm{m})$.

Experimental design

The biological trail contained six groups; each group consisted of 10 rats. Colitis groups were induced in 36-h fasted rats according to Mascolo et al. (1995). Under light ether anaesthesia, a rubber canula was inserted into the colon $(8 \mathrm{~cm}$ from anus), via the anus and a $0.25 \mathrm{ml}$ solution of $16 \%$ acetic acid/ $100 \mathrm{~g}$ body weight was instilled into the lumen of the colon. A histopathological examination of colon sections had been done to be insuring for colon inflammation induction. Group (1) served as normal control (Healthy) and group (4) served as positive control (Colitis) both were administrated $0.5 \mathrm{ml}$ distilled water $/ 100 \mathrm{~g}$ body weight by stomach tube daily. Healthy rats of group (2) and colitis rats of group (5) both were administrated $0.5 \mathrm{ml}$ fresh pineapple juice/100g body weight by stomach tube as well as healthy rats of group (3) and colitis rats of group (6) both were administrated $0.5 \mathrm{ml}$ bromelain $/ 100 \mathrm{~g}$ body 
weight daily using stomach tube. Balanced diet freely were offered to all groups and water ad libitum for 6 weeks.

Serum and tissue analysis

At the end of experimental period, all rats were sacrificed under ether anesthesia after $12 \mathrm{hrs}$ fasting with water ad libitum. Blood samples were collected from hepatic portal vein in two centrifuge tubes. The first one contained ethyelen diamine tetraacetic acid (EDTA) for collecting blood immediately used for the determination of blood GSH concentration by using Beutler et al. (1963) method. The second tube, blood was allowed to left for 15 minutes at temperature of $35^{\circ} \mathrm{C}$, and then centrifuged at $4000 \mathrm{rpm}$ for 10 minutes by EBA8 centrifuge for the separation of serum. Serum was collected and kept in an Eppendorf vials at $-20{ }^{\circ} \mathrm{C}$ until used for biochemical analyses as serum CAT activity as indicated by Aebi (1984) as well as serum inflammatory markers as TNF- $\alpha$, MPO activity and CRP according to the method of Brynskov et al. (2002), Klebanoff (2005) and Hessian and Palmer (1985), respectively. Also, colon was separated and cleaned, immediately rinsed and washed by cold physiological saline solution and then part was used for determination of biochemical assays such as SOD activity and MDA as indicated by Nishikimi et al. (1972) and Uchiyama and Mihara (1978) respectively and another part of colon was fixed in formalin then paraffin sections were stained by Haematoxylin and Eosin, following the technique of Bancraft and Gamble (2008) then examined microscopically at X100, also microscopic scores were calculated according to Hale et al. (2005).

$\underline{\text { Statistical analysis }}$

Data were statistically analyzed by Statistical Package for Social Science (SPSS) version 17.0. Values were presented as mean \pm standard deviation (S.D.). Statistical differences between groups were performed using one way Analysis of Varience (ANOVA), the mean difference was significant at the $(p<0.05)$ level according to Levesque (2007).

\section{Results and Disscussion}

The results of the present study showed content of total phenols, total flavonoids, ascorbic acid and total antioxidant capacity of the fresh pineapple juice as showen in table (1).

Table 1: Total phenols, total flavonoids, ascorbic acid and total antioxidant capacity of the tested fresh pineapple juice

\begin{tabular}{||l||l||}
\hline \multicolumn{1}{|c|}{ Contents } & \multicolumn{1}{c|}{ Values } \\
\hline \hline Total phenols & $425 \pm 3.00 \mathrm{mg} / 100 \mathrm{ml}$ as gallic acid \\
\hline Total flavonoids & $584 \pm 4.00 \mathrm{mg} / 100 \mathrm{ml}$ as catechin \\
\hline Ascorbic acid & $25 \pm 1.00 \mathrm{mg} / 100 \mathrm{ml}$ \\
\hline Total antioxidant capacity & $57 \pm 1.00 \%$ as ascorbic acid \\
\hline
\end{tabular}

Values are mean of three replicates (Mean \pm SD) 
The results revealed that each $100 \mathrm{ml}$ of fresh pineapple juice contains $425 \pm 3.00$ $\mathrm{mg}$ as GAE for total phenols and $584 \pm 4.00 \mathrm{mg}$ as CE for total flavonoids, also $25 \pm 1.00$ $\mathrm{mg}$ ascorbic acid as well as $57 \pm 1.00 \%$ total antioxidant capacity as AAE. Total antioxidant capacity of the tested pineapple juice was resided in its phytochemical contents included; total phenols, total flavonoids and ascorbic acid which have high benefit of reducing oxidative stress and so ameliorate the symptoms of colon inflammation.

Choi and Lee (2009) showed that pineapple juice can be taken to alleviate sore throat and seasickness. The functional bioactivity of a plant extract, in general, depends upon the presence of compounds such as polyphenols, carotenoids and chlorophyll. Also Othman (2011) showed that the ascorbic acid content of freshly harvested fruits was $27.4 \mathrm{mg} / 100 \mathrm{~g}$ in early season fruits and $33.4 \mathrm{mg} / 100 \mathrm{~g}$ in late season fruits.

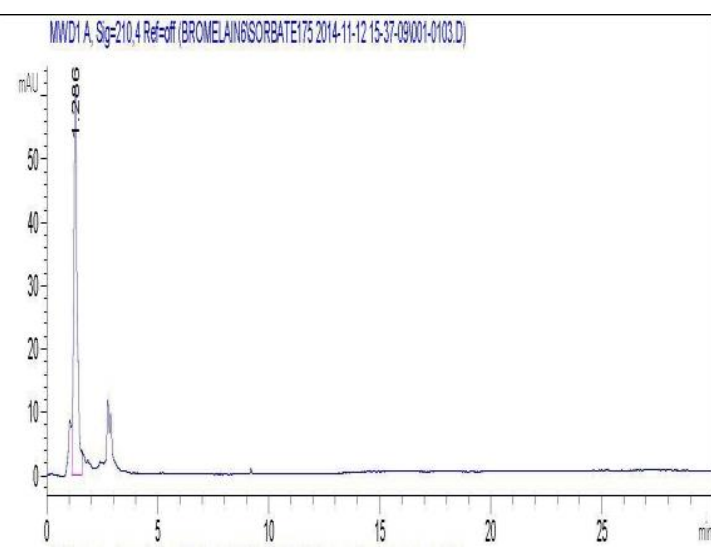

Figure 1-A: HPLC chromatogram of standard pure bromelain

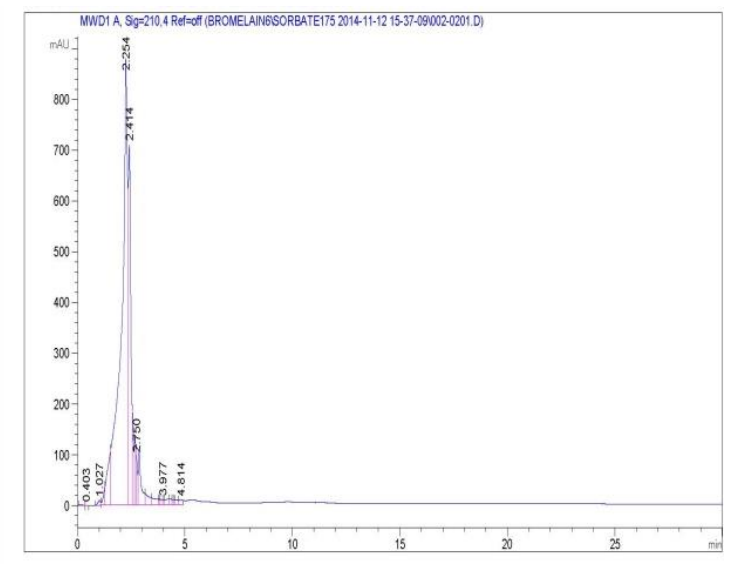

Figure 1-B: HPLC chromatogram of fresh pineapple juice

For determination of bromelain concentration in fresh pineapple juice by HPLC, the chromatogram of standard protein bromelain showed a major peak at a retention time represented with a similar retention time of the pure bromelain used as a standard (Figure 1).

Our results revealed that concentration of bromelain was $12.29 \mathrm{mg} / 100 \mathrm{ml}$ fresh pineapple juice. Maurer (2001) revealed that bromelain is an aqueous extract of pineapple that contains a complex mixture of thiol proteases and non-protease components. Proteases constitute the major components of bromelain and include stem bromelain (80\%), fruit bromelain (10\%), and ananain (5\%). Bartholomew et al. (2003) stated that only modest quantities of bromelain are in the edible parts of the fruit, all commercially available bromelain is derived from the stem. 
Table (2): Effect of consuming fresh pineapple juice or bromelain on antioxidant status and lipid peroxide in healthy and colitis rats

\begin{tabular}{|c|c|c|c|c|}
\hline Groups & $\begin{array}{l}\text { Blood GSH } \\
\quad(\mathbf{m g} / \mathbf{d l})\end{array}$ & $\begin{array}{l}\text { Serum CAT } \\
(\mathbf{U} / \mathbf{m l})\end{array}$ & $\begin{array}{l}\text { Colon SOD } \\
\quad(\mathbf{U} / \mathbf{g})\end{array}$ & $\begin{array}{c}\text { Colon MDA } \\
(\mu \mathrm{mol} / \mathrm{g})\end{array}$ \\
\hline $\begin{array}{l}\text { Healthy rats (Normal } \\
\text { control) }\end{array}$ & $23.12 \pm 0.69$ & $255.03 \pm 4.41$ & $411.02 \pm 8.65$ & $0.14 \pm 0.02^{\mathbf{d}}$ \\
\hline $\begin{array}{l}\text { Healthy rats consumed } \\
\text { fresh pineapple juice }\end{array}$ & $27.98 \pm 0.94^{\mathbf{a}}$ & $283.94 \pm 5.79$ & $\begin{array}{r}\mathbf{b} \\
431.34 \pm 4.63\end{array}$ & $0.10 \pm 0.02^{\mathbf{e}}$ \\
\hline $\begin{array}{l}\text { Healthy rats consumed } \\
\text { bromelain }\end{array}$ & $23.75 \pm 0.55^{\mathbf{b}}$ & $270.61 \pm 5.26$ & $479.44 \pm 6.13^{\mathbf{a}}$ & $0.14 \pm 0.01^{\mathbf{d}}$ \\
\hline $\begin{array}{l}\text { Colitis rats (Positive } \\
\text { control) }\end{array}$ & $10.49 \pm 0.63$ & $182.12 \pm 3.43^{\mathbf{f}}$ & $284.11 \pm 10.16$ & $0.60 \pm 0.02^{\mathbf{a}}$ \\
\hline $\begin{array}{l}\text { Colitis rats consumed } \\
\text { fresh pineapple juice }\end{array}$ & $21.18 \pm 0.46^{\mathbf{c}}$ & $212.70 \pm 3.37$ & $\begin{array}{r}\mathbf{e} \\
388.66 \pm 3.89\end{array}$ & $0.30 \pm 0.02^{\mathbf{c}}$ \\
\hline $\begin{array}{l}\text { Colitis rats consumed } \\
\text { bromelain }\end{array}$ & $18.44 \pm 0.69^{\mathbf{d}}$ & $201.60 \pm 1.24$ & $\begin{array}{r}\text { d } \\
398.56 \pm 2.08 \\
\end{array}$ & $0.42 \pm 0.03^{\mathbf{b}}$ \\
\hline LSD & 0.68 & 4.23 & 6.60 & 0.001 \\
\hline
\end{tabular}

Values are represented (Mean \pm SD) for 8-10 rats for each group.

There was no significant difference between means have the same letter in the same column $(p<0.05)$.

On the other hand, the effect of fresh pineapple juice or bromelain consumption on antioxidant status was shown in (table 2). Acetic acid administration resulted in a significant decreament in nonenzymatic antioxidant as blood GSH and enzymatic antioxidants such as serum CAT and colon SOD by $54.63 \%$, 28.59\% and $30.88 \%$, respectively compared to normal control as well as significant increment in colon MDA result from LPO of membranes by $328.57 \%$ compared to normal control $(P<$ 0.05). While consumption of fresh pineapple juice or bromelain resulted in elevation of level of antioxidant enzymes as blood GSH, serum CAT and colon SOD and significant reduction in MDA level. The mean values of blood GSH, serum CAT, colon SOD and colon MDA were $(21.18 \pm 0.46 \mathrm{mg} / \mathrm{dl}$ vs $18.44 \pm 0.69 \mathrm{mg} / \mathrm{dl})$, $(212.70 \pm 3.37 \mathrm{U} / \mathrm{ml}$ vs $201.60 \pm 1.24 \mathrm{U} / \mathrm{ml}),(388.66 \pm 3.89 \mathrm{U} / \mathrm{g}$ vs $398.56 \pm 2.08 \mathrm{U} / \mathrm{g})$ and $(0.30 \pm 0.02 \mu \mathrm{mol} / \mathrm{g}$ vs $0.42 \pm 0.03 \mu \mathrm{mol} / \mathrm{g})$, respectively for pineapple juice treated colitis rats versus bromelain treated colitis rats compared to colitis control $(10.49 \pm 0.63 \mathrm{mg} / \mathrm{dl})$, $(182.12 \pm 3.43 \mathrm{U} / \mathrm{ml}),(284.11 \pm 10.16 \mathrm{U} / \mathrm{g})$ and $(0.60 \pm 0.02 \mu \mathrm{mol} / \mathrm{g})$, respectively $(P<0.05)$.

Hartmann et al. (2012) explained that the acetic acid induced colitis model is known to cause vascular dilatation and white blood cells accumulation, as well as an increase in blood flow, leading to increase production of oxygen and hence the excessive generation of free radical and ROS. Al-Rejaie et al. (2013) showed that acetic acid administration markedly reduced total GSH compared to control (3.04 \pm $0.24 \mathrm{nmol} / \mathrm{L}$ vs $5.25 \pm 0.37 \mathrm{nmol} / \mathrm{L}, P<0.01)$, CAT $(3.04 \pm 0.2 \mathrm{U} / \mathrm{mg}$ vs $6.77 \pm 0.40$ 
$\mathrm{U} / \mathrm{mg}, P<0.01)$ and SOD $(1.77 \pm 0.18 \mathrm{U} / \mathrm{mg}$ vs $3.10 \pm 0.11 \mathrm{U} / \mathrm{mg}, P<0.01)$, while NO level was increased compared to control $(101.90 \pm 10.73 \mathrm{mmol} / \mathrm{g}$ vs $81.26 \pm 2.98$ $\mathrm{mmol} / \mathrm{g}, P<0.001)$. The levels and activities of non-enzymatic and enzymatic defense systems were severely decreased in the colon of acetic acid administered animals indicating oxidative cellular injury.

Aiyegbusi et al. (2011) demonstrated that bromelain had no significant $(P<0.05)$ effect on the reduction of MDA level $(0.98 \pm 0.10 \mu \mathrm{mol} / \mathrm{mg})$ compared with the injured untreated group $(0.99 \pm 0.14 \mu \mathrm{mol} / \mathrm{mg})$, whereas fresh pineapple juice significantly reduced the MDA value $(0.73 \pm 0.08 \mu \mathrm{mol} / \mathrm{mg})$. They explained that bromelain's effect in reducing the MDA level was very marginal, unlike pineapple juice, which significantly lowered the MDA content compared with the other groups.

Table (3): Effect of consuming fresh pineapple juice or bromelain on serum inflammatory markers in healthy and colitis rats

\begin{tabular}{|c|c|c|c|}
\hline $\begin{array}{ll}\text { Groups } & \text { Parameters } \\
\end{array}$ & $\begin{array}{l}\text { TNF- } \alpha \\
(\mathrm{pg} / \mathrm{ml})\end{array}$ & $\begin{array}{l}\text { MPO } \\
(\mathbf{n g} / \mathbf{m l})\end{array}$ & $\begin{array}{c}\text { CRP } \\
(\mathrm{mg} / \mathrm{L})\end{array}$ \\
\hline Healthy rats (Normal control) & $152.60 \pm 7.50^{\text {d }}$ & $10.55 \pm 0.15^{\text {d }}$ & $3.47 \pm 1.23^{\mathbf{c}}$ \\
\hline $\begin{array}{l}\text { Healthy rats consumed fresh } \\
\text { pineapple juice }\end{array}$ & $128.03 \pm 2.73$ & $9.14 \pm 0.44^{\mathbf{e}}$ & $3.18 \pm 1.20$ \\
\hline Healthy rats consumed bromelain & $91.72 \pm 2.78$ & $9.01 \pm 0.23^{\mathbf{e}}$ & $3.47 \pm 1.23$ \\
\hline Colitis rats (Positive control) & $263.59 \pm 5.49^{\mathbf{a}}$ & $23.34 \pm 0.34^{\mathbf{a}}$ & $10.82 \pm 1.84^{\mathbf{a}}$ \\
\hline $\begin{array}{l}\text { Colitis rats consumed fresh } \\
\text { pineapple juice }\end{array}$ & $171.94 \pm 6.70^{\text {c }}$ & $14.31 \pm 0.12^{\mathbf{c}}$ & $5.48 \pm 1.19^{\mathbf{b}}$ \\
\hline Colitis rats consumed bromelain & $209.37 \pm 3.89^{\text {b }}$ & $14.79 \pm 0.87^{\mathbf{b}}$ & $5.20 \pm 1.06^{\mathbf{b}}$ \\
\hline LSD & 5.24 & 0.26 & 1.33 \\
\hline
\end{tabular}

Values are represented (Mean \pm SD) for 8-10 rats in each group.

There was no significant difference between means have the same letter in the same column $(p<0.05)$.

TNF- $\alpha$ is a potent pleiotropic, proinflammatory cytokine produced by many cells in response to injury and inflammation. Babbar and Casero, (2006) showed that TNF- $\alpha$ exposure results in increased production of ROS, with a concomitant increase in the production of 8-hydroxydeoxyguanine (8-OHDG), a marker for oxidative DNA damage in human lung bronchial epithelial cells.

CRP is known as a marker of inflammation. CRP acts as an opsonin and activates complement leading to phagocytosis of nuclear components and bacterial sequences. The production of CRP occurs almost exclusively in the liver by the hepatocytes as part of the acute phase response upon stimulation by interleukin-6 (IL6), TNF- $\alpha$ and IL-1- $\beta$ originating at the site of inflammation (Vermeire et al., 2004). 
MPO is an enzyme stored in azurophilic granules of polymorphonuclear neutrophils and macrophages and released into extracellular fluid in the setting of inflammatory process. It was observed that MPO was involved in oxidative stress and inflammation (Loria et al., 2008).

Inflammatory marker cytokine, enzyme and component TNF- $\alpha$, MPO and CRP respectively were significantly increase UC group by $72.73 \%, 121.23 \%$ and $211.82 \%$, respectively compared to normal control. After treatment by pineapple juice, the level of TNF- $\alpha$, MPO and CRP decreased by $34.77 \%, 38.69 \%$ and $49.35 \%$, respectively compared to colitis control $(P \prec 0.05)$, while after treatment by bromelain, their levels decreased by $20.57 \%, 36.63 \%$ and $51.94 \%$, respectively compared to colitis control (table 3). Hale et al. (2002) illustrated the efficacy of fresh pineapple juice treatment on chronic colitis, when the bromelain concentration used in the diluted juice used for these assays $(340 \mu \mathrm{g} / \mathrm{ml})$ is less than the $1 \mathrm{mg} / \mathrm{ml}$ used in reports using bromelain purified from stem. They also demonstrated that, similar to bromelain purified from stem, bromelain present in fresh pineapple juice can also remove cell surface molecules known to affect leukocyte migration and function. CD44, CD45R, CD62L, and CD8 were found to be at least partially sensitive to removal by exposure to fresh juice. Onken et al. (2008) stated that bromelain treatment reduced secretion of several proinflammatory cytokines and chemokines that have been showen to be elevated in IBDs. Bromelain treatment thus potentially resulted in decreased leukocyte migration to the colon and decreased overall inflammatory activity. 


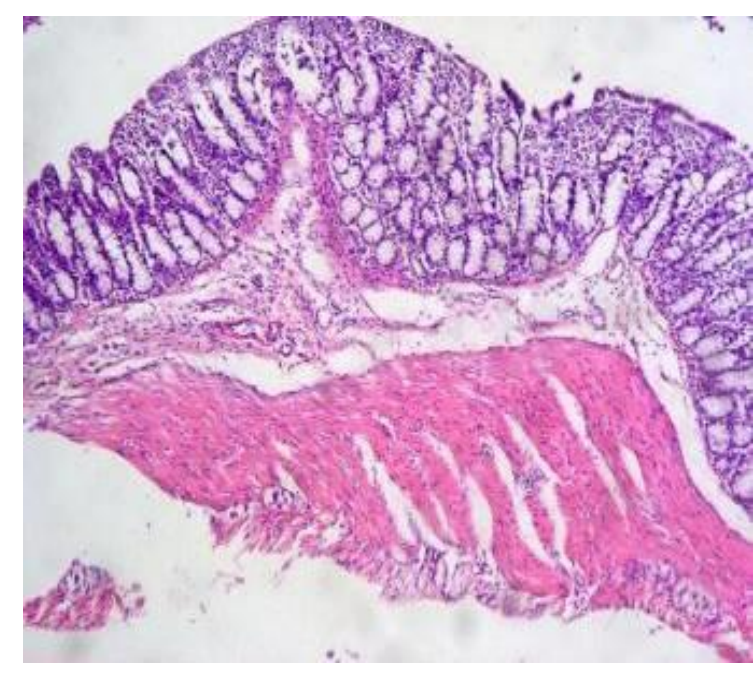

Figure (2): Microscopic appearance of transverse section for healthy rats (normal control) shows a normal colonic specimen, stained with Haematoxylin and Eosin (H\&E; $\mathrm{x} 100)$.

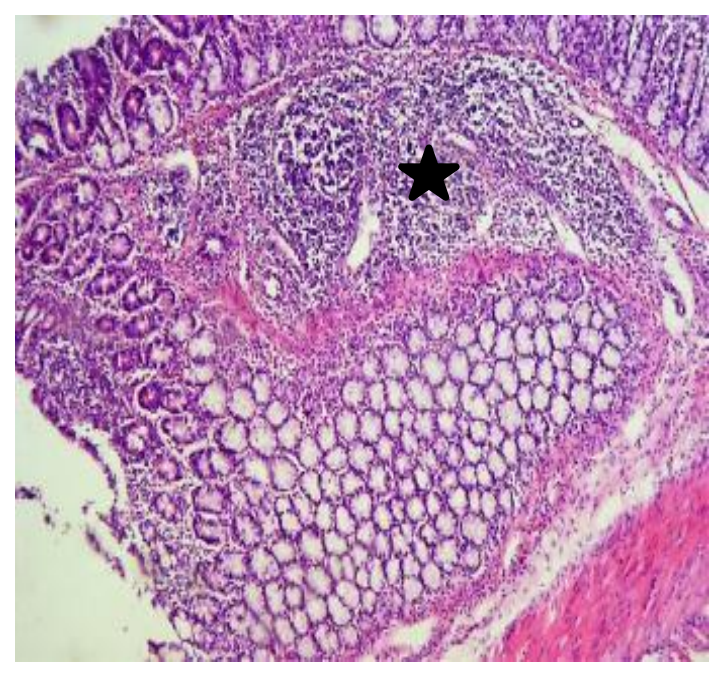

Figure (3): Microscopic appearance of transverse section for colitis rats that induced by acetic acid showed an intact mucosa and dense mixed inflammatory cellular infiltrate with lymphoid aggregate formation $(\boldsymbol{\star})$, stained with Haematoxylin and Eosin (H\&E; x100).

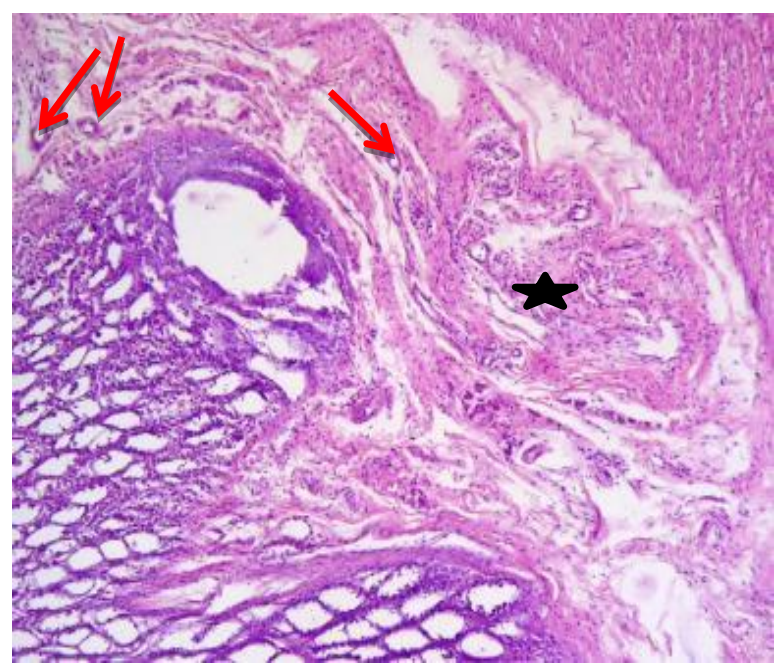

Figure (4): Microscopic appearance of transverse section for colitis rats treated with fresh pineapple juice showed an intact mucosa with expansion by edema and mild mixed inflammatory cellular infiltrate $(\boldsymbol{\star})$. Congested blood vessels are also seen $(\downarrow)$, stained with Haematoxylin and Eosin (H\&E; x100).

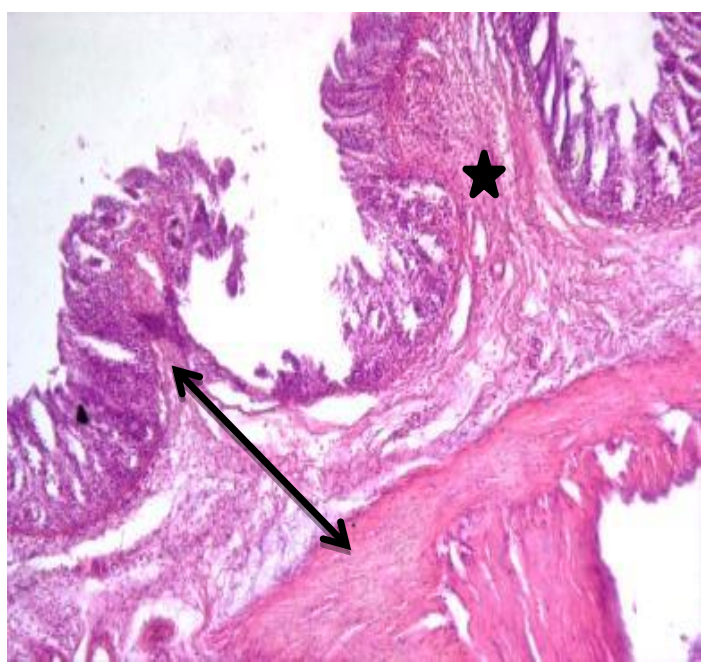

Figure (5): Microscopic appearance of transverse section for colitis rats treated with bromelain showed ulceration with expansion (Arrowed area) by edema and moderate mixed inflammatory cellular infiltrate ( stained with Haematoxylin and Eosin (H\&E; x100). 
Table (4): Microscopic scoring of colon tissue in healthy and colitis rats treated with fresh pineapple juice or bromelain

\begin{tabular}{|l||c||c||c||c||c||}
\hline Groups & Ulceration & Hyperemia & Necrosis & Edema & $\begin{array}{l}\text { Cellular } \\
\text { Infiltirate }\end{array}$ \\
\hline \hline Healthy rats & 0 & 0 & 0 & 0 & 0 \\
\hline $\begin{array}{l}\text { Healthy rats consumed } \\
\text { fresh pineapple juice }\end{array}$ & 0 & 0 & 0 & + & 0 \\
\hline $\begin{array}{l}\text { Healthy rats consumed } \\
\text { bromelain }\end{array}$ & 0 & 0 & 0 & 0 & 0 \\
\hline $\begin{array}{l}\text { Colitis rats } \\
\begin{array}{l}\text { Colitis rats consumed } \\
\text { fresh pineapple juice }\end{array}\end{array}$ & 0 & ++ & 0 & + & + \\
\hline $\begin{array}{l}\text { Colitis rats consumed } \\
\text { bromelain }\end{array}$ & + & 0 & 0 & + & ++ \\
\hline
\end{tabular}

Normal: 0; Mild: +; Moderate: ++; Severe: +++

Microscopic examination of the colonic specimens of the control group revealed intact mucosal epithelium of tall columnar epithelial cells (Figure 2). In the diseased group, the colonic specimens revealed focal mucosal ulcerations, focal areas of necrosis (reaching to marked sever score) associated with severe edema, inflammatory cellular infiltrate with frequent transmural dense inflammation extending to the serosal surface, frequent lymphoid aggregates (Figure 3). The treated group with fresh pineapple juice or bromelain showed intact mucosal epithelium, significantly fewer mucosal inflammatory cellular infiltrate with variable degree of stromal edema and disappearance of the transmural inflammation being limited only to the mucosa and the submucosa (Figure 4\&5 Table 4).

D'Argenio et al. (2012) demonstrated that UC induced by acetic acid is characterized by mucosal inflammation and ulcerations with a variable extent and severity. Hartmann et al. (2012) showed that colitis also causes colonic epithelial lesions and necrosis associated with neutrophils and macrophages infiltration to the damaged colon indicating inflammatory conditions. Furthermore, Al-Rejaie et al. (2013) illustrated that $4 \%$ acetic acid administration resulted in a significant increase in colonic weight and induced sever ulceration and tissue necrosis associated with inflammatory infiltrate and goblet cell hyperplasia.

Hale et al. (2005) studied the effect of bromelain on microscopic changes compared to colitis group. Microscopic evaluation showed moderate colitis in the control group (Mean histologic score $\pm \mathrm{SEM}=29 \pm 5$ ) as colonic lesions in control group included mild to moderate mucosal hyperplasia, infiltrates of mononuclear and polynuclear leukocytes into the mucosa and/or submucosa, frequent mucosal erosions in association with focally extensive apoptosis of colonic epithelial cells, and mucosal ulcerations. However, mice treated with $5 \mathrm{mg}$ bromelain/day had only small foci of active intestinal inflammation (Mean histologic score $\pm \mathrm{SEM}=15 \pm 2 ; \mathrm{P}=0.04$ vs. control). Thus, daily treatment with $5 \mathrm{mg}$ bromelain significantly decreased colon inflammation. 
The microscopic examination of fresh pineapple juice treated rats showed more improvement with less inflammatory infiltrate which matched with results of Hale et al. (2011) who showed that the colonic inflammation was significantly decreased in mice that received fresh juice (mean histologic score $\pm S E M=29 \pm 4$ ) compared with mice that received boiled juice (mean histologic score \pm SEM $=39 \pm 3 ; \mathrm{p}=0.05$ ). While mice treated with bromelain had moderate colitis with histologic scores \pm SEM $=31 \pm 4)$.

Barada et al. (2006) explained the correlation between the temporal evolution of cytokine levels and that of the ulcer scores. Ulceration in the colon was observed as early as $3 \mathrm{~h}$ after iodoacetamide or trinitrobenzene sulfonic acid (TNBS) administration and was associated with marked induction of TNF- $\alpha$ and IL-6 production. As inflammation in the colon started to subside, the levels of the cytokines returned towards control values in the iodoacetamide model. In the TNBS model, however, TNF- $\alpha$ levels remained elevated 3 weeks after induction despite significant healing of the colonic ulcer. These results suggest a possible role for these cytokines in the colonic inflammatory state.

The present investigation outlines the anti-ulcerogenic effect of fresh pineapple juice or bromelain against experimentally induced UC in rats as a model for IBDs. The preventive effect of treatments was confirmed by histological evaluation. The treatment with fresh pineapple juice or bromelain significantly reduced the acetic acid induced colonic mucus content and prevented oxidative and inflammatory response.

\section{Conclusion}

The fresh pineapple juice consumption has a vital role in alleviate the severity of colitis by ameliorating the oxidative stress status due to its high content of antioxidant as well as bromelain that acts as immunomodulatory by removing bromelain-sensitive molecules and thus decreasing proinflammatory cytokines such as TNF- $\alpha$.

\section{Acknoweldgment}

The authors are grateful to Dr. Wesam M. Osman, associate professor of pathology. Pathology department, Ain Shams University for her help in microscopic examination of colon sections and the microscopic scoring of histopathological sections of colon. Also, we thank Prof. Dr.Hany A. Fahmy, professor of special food and nutrition. Microanalysis lab in special food and nutrition department, Food Technology Research Institute for his effort in HPLC work.

\section{References}

Aebi H, Catalase in vitro. Methods Enzymol., 105: 121-126 (1984).

Aiyegbusi AI, Olabiyi OO, Duru FIO, Noronha CC and Okanlawon AO, A Comparative study of the effects of bromelain and fresh pineapple juice on the early phase of healing in acute crush achilles tendon injury. J Med Food., 14 (4) : 348-352 (2011). 
Al-Rejaie SS, Abuohashish HM, Al-Enazi MM, Al-Assaf AH, Parmar MY and Ahmed MM, Protective effect of naringenin on acetic acid-induced ulcerative colitis in rats. World J Gastroenterol., 19(34): 5633-5644 (2013).

Alzoghaibi MA, Concepts of oxidative stress and antioxidant defense in Crohn's disease. World J Gastroenterol., 19(39):6540-6547 (2013).

AOAC, Association of Official Analytical Chemists. Ascorbic acid: vitamin preparation and juices, 2, 6 dicholoroindophenol titremetric method. $18^{\text {th }}$ Edition, Gaithersburg, Maryland and USA (2006).

Babbar $\mathbf{N}$ and Casero RAJr, Tumor necrosis factor- $\alpha$ increases reactive oxygen species by inducing spermine oxidase in human lung epithelial cells: a potential mechanism for inflammation-induced carcinogensis. Cancer Res., 66(23): 1112511130 (2006).

Bancroft JD and Gamble M, Theory and practice of histological techniques. $6^{\text {th }}$ Ed., Churchill-Liviston, Elsevier, China (2008).

Barada KA, Mourad FH, Sawah SI, Khoury C, Safieh-Garabedian B, Nassar CF and Saadé NE, Localized colonic inflammation increases cytokine levels in distant small intestinal segments in the rat. Life Sci., 79: 2032-2042 (2006).

Bartholomew DP, Paull RE and Rohrbach KG, The Pineapple: botany, production and uses, CABI Publishing, Wallingford UK., 21 (2003).

Beutler E, Duron $\mathrm{O}$ and Kelly BM, Improved method for the determination of blood glutathione. J Lab Clin Med., 61(5): 882-888 (1963).

Bhattacharyya BK, Bromelain: An overview. Nat Prod Rad., 7(4): 359-363 (2008).

Brynskov J, Foegh P, Pedersen G, Ellervik C, Kirkegaard T, Bingham A and Saermark T, Tumour necrosis factor alpha converting enzyme (TACE) activity in the colonic mucosa of patients with inflammatory bowel disease. Gut. 51 (1): 3743(2002).

Calder PC, $\mathrm{n} \_3$ Polyunsaturated fatty acids, inflammation, and inflammatory diseases. Am J Clin Nutr., 83(suppl):1505S-1519S (2006).

Choi $\mathbf{Y}$ and Lee J, Antioxidant and antiproliferative properties of a tocotrienolrich fraction from grape seeds. Food Chem., 114: 1386-1390 (2009).

Danino O, Gottlieb HE, Grossman S and Bergman M, Antioxidant activity of 1, 3dicaffeoylquinic acid isolated from Inula viscosa. Food Res Int., 42(9): 1273-1280 (2009).

D’Argenio G, Mazzone G, Tuccillo C, Ribecco MT, Graziani G, Gravina AG, Caserta S, Guido S, Fogliano V, Caporaso N and Romano M, Apple polyphenols extract (APE) improves colon damage in a rat model of colitis. Dig Liver Dis., 44: 555-562 (2012).

Gardner PT, White TAC, McPhailD B and Duthie GG, The relative contribution of vitamin $\mathrm{C}$, carotenoids and phenolics to the antioxidant potential of fruit juices. Food Chem., 68: 471-474 (2000).

Hale LP, Chichlowski M, Trinh CT and Greer PK, Dietary supplementation with fresh pineapple juice decreases inflammation and colonic neoplasia in il-10-deficient mice with colitis. Inflamm Bowel Dis., 16(12): 2012-2021(2011). 
Hale LP, Greer PK and Sempowski GD, Bromelain treatment alters leukocyte expression of cell surface molecules involved in cellular adhesion and activation. Clin Immunol., 104: 183-190 (2002).

Hale LP, Greer PK, Trinh CT and Gottfried MR, Treatment with oral bromelain decreases colonic inflammation in the IL-10- deficient murine model of inflammatory bowel disease, Clin Immunol., 116 : 135-142 (2005).

Hartmann RM, Morgan Martins MI, Tieppo J, Fillmann HS and Marroni NP, Effect of Boswellia serrata on antioxidant status in an experimental model of colitis rats induced by acetic acid. Dig Dis Sci., 57: 2038-2044 (2012).

Hessian PA and Palmer DG, The presence and possible significance of C - reactive protein in rheumatoid inflammation. J Rheumatol., 12:871-875 (1985).

Hibi T, Ogata H and Sakuraba A, Animal models of inflammatory bowel disease. J Gastroenterol., 37: 409- 417 (2002).

Isabelle M, Lee BL, Lim MT, Koh MT, Huang D and Nam C, Antioxidant activity and profiles of common fruits in Singapore. Food Chem., 123: 77-84 (2010).

Klebanoff SJ, Myeloperoxidase: friend and foe. J Leuko Biol., 77(5): 598-625 (2005).

Levesque R, SPSS programming and data management: A Guide for SPSS and SAS user. $4^{\text {th }}$ Edition, SPSS Inc, Chicago, IL (2007).

Loria V, Dato I, Graziani F and Biasucci LM, Myeloperoxidase: A new biomarker of inflammation in ischemic heart disease and acute coronary syndromes. Mediat Inflamm., (10): 1-4 (2008).

Lo'pez-Garci'a B, Herna'ndez $M$ and Segundo BS, Bromelain, a cysteine protease from pineapple (Ananas comosus) stem, is an inhibitor of fungal plant pathogens. Lett Appl Microbiol., 55: 62-67 (2012).

Mascolo N, Izzo A, Autore G, Maiello F, Di-Carlo G and Capasso F, Acetic acidinduced colitis in normal and essential fatty acid deficient rats. J Pharmacol and Exp Ther., 272: 469-475 (1995).

Maurer HR, Bromelain: biochemistry, pharmacology and medical use, Cell Mol Life Sci., 58: 1234-1245 (2001).

Mhatre M, Tilak-Jain J, De S and Devasagayam TPA, Evaluation of the antioxidant activity of non-transformed and transformed pineapple: A comparative study. Food Chem Toxicol., 47: 2696-2702 (2009).

Mondal S, Bhattacharya S, Pandey JN and Biswas M, Evaluation of acute antiinflammatory effect of Ananas Comosus leaf extract in Rats. Pharmocology.3: 13121315 (2011).

Nicholls RJ, Review article: ulcerative colitis- surgical indications and treatment. Aliment Pharmacol Ther., 16(suppl 4): 25- 28 (2002).

Nishikimi M, Roa NA and Yogi K, Measurement of superoxide dismutase. Biochem Biophys Res Common., 46:849-854 (1972).

Onken JE, Greer PK, Calingaert B and Hale LP, Bromelain treatment decreases secretion of pro-inflammatory cytokines and chemokines by colon biopsies in vitro. Clin Immunol., 126:345-352 (2008). 
Othman OC, Physicochemical characteristics and levels of inorganic elements in offvine ripened pineapple (Ananas comosus L.) fruits. KIST Journal of Science and Technology. 1(1):23-30 (2011).

Pravda J, Radical induction theory of ulcerative colitis. World J Gastroenterol., 11: 2371-2384 (2005).

Prieto P, Pineda M and Aguilar M, Spectrophotometric quantitation of antioxidant capacity through the formation of a phosphomolybdenum complex: Specific application to the determination of vitamin E. Anal Biochem., 269: 337-341 (1999).

Quettier DC, Gressier B, Vasseur J, Dine T, Brunet C, Luyckx MC, Cayin JC, Bailleul $\mathbf{F}$ and Trotin F, Phenolic compounds and antioxidant activities of buckwheat (Fagopyrum esculentum Moench) hulls and flour. J Ethnopharmacol., 72: 35-42 (2000).

Reeves PG, Nielsen FH and Fahey Jr, Ain-93 purified diets for laboratory rodents: final report of the american institute of nutrition ad hoc writing committee on the reformation of AIN-76A rodent diet. J Nutr., 123: 1939-1951 (1993).

Selling JH and Pasricha PJ, Pharmacotherapy of inflammatory bowel disease. In: Gilman's G, editor. The Pharmacological Basis of Therapeutics. New York: McGrawHill Publications (2006).

Singleton VL, Orthofer R and Lamuela-raventos RM, Analysis of total phenols and other oxidation substrates and antioxidants by means of Folin-Ciocalteu reagent. Methods Enzymol., 299: 152-178 (1999).

Uchiyama $M$ and Mihara M, Determination of malondialdehyde precursor in tissue by thiobarbituric acid method. Anal Biochem., 86: 271-278 (1978).

Vermeire S, Van Assche GV and Rutgeerts P, C-reactive protein as a marker for inflammatory bowel disease. Inflamm Bowel Dis., 10(5):661-665 (2004). 
الملخص باللغة العربية

تأثير استهلاك عصير الأناناس الطازج (Ananas Cosmosus) أو البروميلين على التهاب القولون المحدث بواسطة حمض الخليك فى الجرذان

\section{فاطمة عبد الحميد خليل- نورا لحما الثيخ- هدير هيثم محمد مارية \\ قسم الكيمياء الحيو ية والتغذيةــ كلية البناتـ جامعة عين شمس}

لتقبيم تأثير عصير الأناناس الطازج أو البروميلين على التهاب القولون المحدث بواسطة حمض الخليك, كذللك

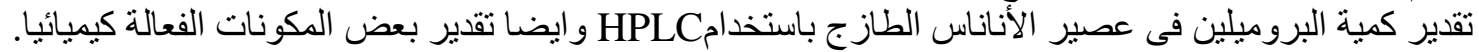

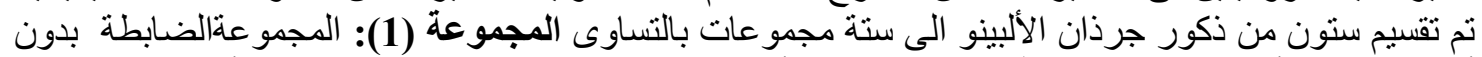

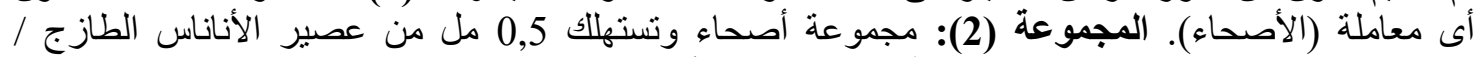

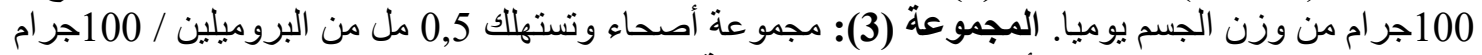

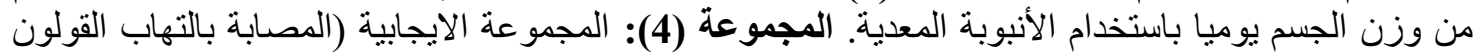

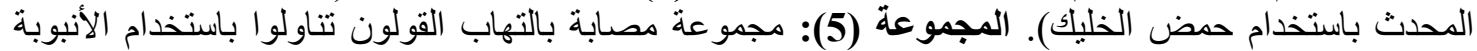

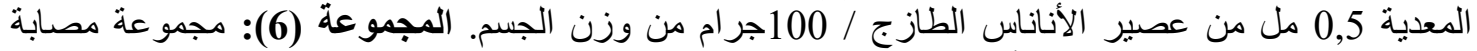

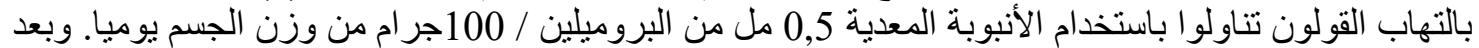

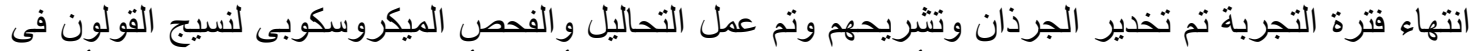

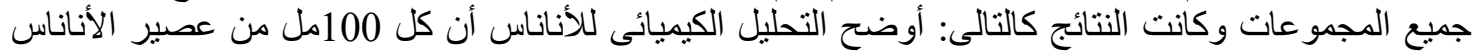

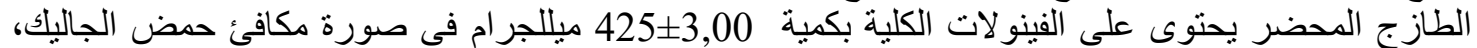

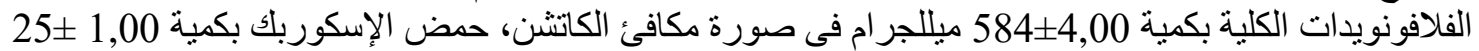

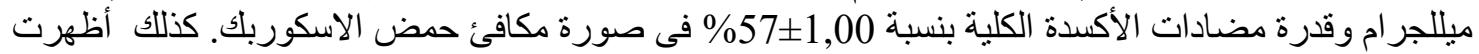

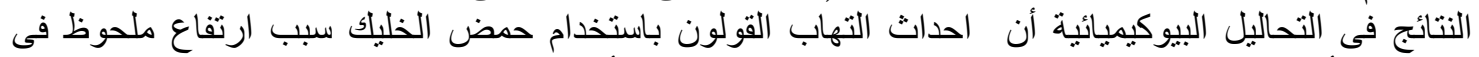

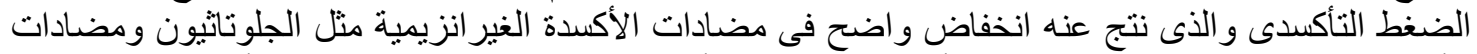

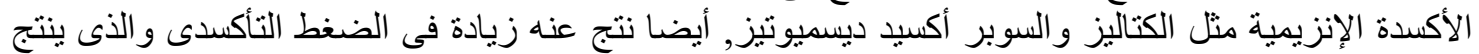

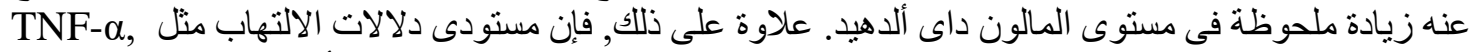

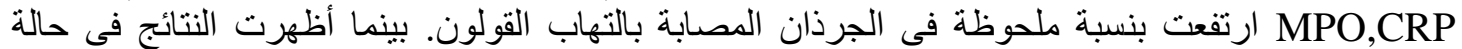

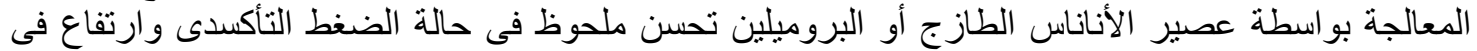

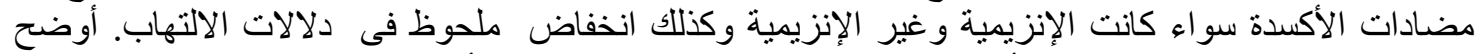

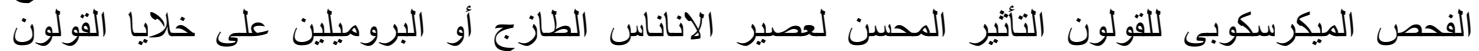

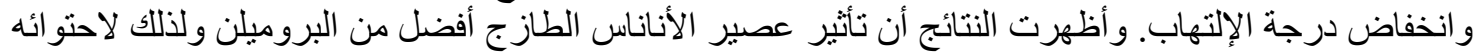
على محتوى عالى من مضادات الأكسدة الطبيعية بالإضافة إلى الثى البروميلين. 